\title{
The Influence of Internet-Based Customer Relationship Management on Customer Loyalty
}

\author{
Aris Y. C. Lam \\ Hong Kong Polytechnic University \\ E-Mail: sparis@speed-polyu.edu.hk \\ Ronnie Cheung \\ University of South Australia \\ E-Mail: ccheung@acm.org \\ Mei Mei Lau \\ Hong Kong Polytechnic University \\ E-Mail: spmay@speed-polyu.edu.hk
}

\begin{abstract}
This research investigates the relationship between the marketing efforts of electronic customer relationship management (e-CRM) and loyalty in Hong Kong's banking industry. A quantitative approach was employed, and 119 valid questionnaires were collected from 150 respondents. All the respondents are account holders of HSBC (the Hong Kong and Shanghai Banking Corporation Limited), the largest bank in Hong Kong. Reliability testing and multiple regression analysis were used to determine the relationships between various independent and dependent variables. The results suggest that all four e-CRM marketing tactics (direct mail, interpersonal communication, preferential treatment, and tangible rewards) play important roles in building customer relationships. There were also significant relationships between the e-CRM marketing tactics and customer relationship quality. The study also found that the latter has a positive impact on customer loyalty. The research results indicate that thorough implementation of e-CRM marketing efforts will heighten customer loyalty towards HSBC.
\end{abstract}

Keywords: e-CRM, Customer Loyalty, Relationship Quality, Banking industry, Hong Kong 


\section{INTRODUCTION}

Customer relationship management (CRM) has been a popular marketing strategy for decades. With the growing global penetration of the Internet, electronic customer relationship management (e-CRM) has become increasingly popular as a communication tool and relationship-building platform. Organizations are keen to deploy different types of e-CRM tactics to attract, maintain, and enhance customer relationships, as they believe good customer relationships are beneficial to loyalty and profitability of the organization (Reichheld, 1996; Winer, 2001).

e-CRM is particularly critical to the success of businesses in Hong Kong since Internet usage by Hong Kong residents has reached 87\%, which is the highest in Asia (Nielsen, 2011), thanks to the ubiquitous use of smart phones and tablet PCs, and also the increasing popularity of social media such as Facebook and Weibo. Other than information search and email communication, about $40 \%$ of Hong Kong customers are using the Internet for banking services and bill payments (Nielsen, 2011).

Hong Kong's service sector has expanded rapidly in recent years, and service industries contribute 93\% of Hong Kong's GDP (HKSAR Government, 2012). Amongst these industries, "financing and insurance" is the largest and one of the fastest growing $(5.7 \%$ in 2012) (HKSAR Government, 2012). The HKSAR Government's economic strategy is to "build Hong Kong as an international financial centre." The unsurpassed importance of the banking industry in Hong Kong and the uniqueness of the Internet usage behavior of customers make it essential for bankers and marketers to understand the importance of different e-CRM tactics, and their contribution to customer relationship and loyalty.

Hong Kong's financial market is highly liquid and transparent, and it has to contend with minimal government intervention. In 2011, there were 150 licensed banks from 34 countries operating 1,400 branches (HKSAR Government, 2011). Globally, Hong Kong was ranked first in terms of economic freedom, came sixth in terms of foreign exchange market turnover (HKSAR Government, 2011), and is one of the top 10 international banking centres (The Standard, 2011). The liberalization of Hong Kong's banking sector by the Hong Kong Monetary Authority (HKMA) since 2001 has resulted in the presence of more foreign and mainland banks, which on the one hand has boosted Hong Kong's position as an international financial centre and opened up the foreign banking market. On the other hand, it has made the Hong Kong banking sector more competitive.

Since its inception in 1865, Hong Kong and Shanghai Banking Corporation Limited (HSBC) has been Hong Kong's largest bank, one that enjoys deep-rooted connections with businesses and customers in this vibrant city. Headquartered in 
London since 1993, HSBC operates in five regions, and its network extends to Europe, Hong Kong, the Middle East, Africa, and North and South America (HSBC, 2011). It is the world's second-largest bank (Forbes, 2011), has an immense operational infrastructure in Asia, and provides banking services around the world. As an indispensable player in the banking sector in Hong Kong and the world, HSBC can be representative of the industry in Hong Kong and perhaps Asia. Therefore, we investigate customers' relationship with HSBC in this study.

In order to be successful and continue to grow organically in a highly competitive market like the banking industry in Hong Kong, attracting new customers is simply insufficient. Service providers like HSBC have to focus their efforts on customer retention in order to survive and continue to grow. Accordingly, HSBC should invest in long-term relationship marketing and be customer oriented in providing services. With the growing popularity and importance of the Internet, HSBC should leverage this powerful communication tool to build, maintain, and enhance relationships with its customers. On top of making the Internet and mobile banking convenient, and enabling customers to access information from its official website, banks have been trying to gain leverage from the popular use of e-banking to market their products and strengthen their relationships with customers. With the assistance of the Internet and database management, HSBC should be able to target the right group of customers in an effective and efficient manner.

Literatures related to the efforts and impacts of e-CRM in general are available, but studies in e-CRM in different cultures that reflect differences in Web-surfing behaviors are rather limited. There are limited studies on the banking industry in Hong Kong. This research, therefore, is designed to address several problems. The main objective is to test and ascertain the effectiveness of e-CRM in Hong Kong's banking industry through the study of customers' relationship with HSBC. In this study, we investigate the influence of the affects of e-CRM on relationship quality, which in turn affects loyalty. With these insights, bankers and marketers can make more informed decisions on whether or not to invest in various types of e-CRM marketing tactics, which will hopefully increase their profitability and spawn continuous growth in their business in the highly competitive market, through relationship building with customers. 


\section{LITERATURE REVIEW AND THEORETICAL FRAMEWORK}

\section{Relationship Marketing}

Relationship marketing refers to marketing activities used to establish, develop, and maintain successful relationships with customers (Morgan and Hunt, 1994; Palmatier et al., 2006). Effective use of relationship marketing can help to enlarge the customer base, and increase market share and profit (Gronroos, 1994). According to Dwyer et al. (Dwyer et al., 1987), attention to customers fosters relational bonds that will lead to repeat purchases that benefit both business and consumer marketing. A positive relationship between customer and company will create customer satisfaction and loyalty (Morris, 1999). Satisfied and loyal customers tend to spend more money and purchase repeatedly, are less price sensitive, have higher intention to refer others, and are more economical to maintain (Duncan and Moriaty, 1998; Reichheld and Sasser, 1990; Yin, 1999). Hence, loyal customers are vital to the survival and success of many service industries, especially in the hospitality, insurance, and financial sectors (Rahman, 2005). A slight change in the percentage of loyal customers is said to bring about a huge change in profits and also the overall value of the company (Rahman, 2005). Marketers are hence eager to understand the key to building strong, long-lasting customer relationships.

\section{Customer Relationship Management (CRM) and the Internet}

CRM is a strategy for companies to build and manage long-term relationships with their customers (Mojtaba, 2009). It is evident that CRM implementation enables better customer service, allows better management of customer expectations, and improves customer loyalty (Cho et al., 2001; Reichheld, 1996; Reichheld and Sasser, 1990; Romano, 2001; Winer, 2001). Effective management of customer relationships directly boosts company profitability (Bolton et al., 2004).

The Internet can help companies to understand customers' needs and wants, satisfy customers' needs through the development of customer-centric marketing programs, and create value for customers by managing data and providing personalized products and services (Iyer et al., 2002; Sheth et al., 2000). Through the online channel, companies can build relationships, segment and retain customers (Campbell, 1997; Hanson, 2000; Jackson and Wang, 1994), and maintain customer loyalty (Forchit and Cochran, 1999).

Integration of CRM and Internet technologies helps companies to build competitive advantages (Chaston and Mangles, 2003), enables companies to build relationships with customers, and enhances customer satisfaction (Krishnan and 
Ramaswamy, 1999; Thorbjornsen et al., 2002). Some believe that without the assistance of Internet tools, CRM cannot be effective (Bradshaw and Brash, 2001; Hamid and Kassim, 2004; Zineldin, 2000).

\section{e-CRM Marketing Efforts and Loyalty}

Electronic Customer Relationship Management (e-CRM) is a management approach that is widely used in today's business world. It refers to marketing activities, tools and techniques delivered through the Internet, using technologies such as email, the worldwide Web, chat rooms, forums, social media, etc., with the goal of locating, building, and improving long-term customer relationships (Lee-Kelley et al., 2003). e-CRM generally refers not only to the technology used in managing customer relationships, but also to the business management processes employed with customer strategies. Chaston and Mangles (Chaston and Mangles, 2003) define e-CRM as "the use of internet technologies to facilitate the management of customer relationships."

The Internet offers unprecedented transparency for customers and marketers, way beyond the capabilities of any traditional media (Porter, 2001). After establishing a relationship with a company, Internet customers are found to gradually double their spending over a period of about two years (Reichheld and Schefter, 2000). Effective e-CRM strategy enables a company to access new international consumers and suppliers and capture valuable stakeholder data, which is essential to a company's growth and market competitiveness (Harrigan et al., 2008). Hence, e-CRM has received increasing attention from different organizations around the world.

\section{Electronic Direct Mailing (e-DM)}

Electronic direct mailing (e-DM) is known as an online newsletter or e-mail an organization uses to keep customers informed (Yoon et al., 2008). Electronic direct mailing facilitates the personalization of relationships. Companies can record the purchase history and preferences of customers, tailor offers and predict future behavior (Day and Hubbard, 2003), and communicate unique offers to customers. Compared to traditional advertising efforts, e-DM allows companies to stimulate individual customers' purchasing interest by making unique offers, without alienating other customers, as they do not receive the same offers. The cost advantage of e-DM enables companies to tailor communication messages to each individual customer and personalize the relationship with them in a cost-efficient way. When the company is able to better serve customers' needs, it improves customer loyalty, efficient deployment of resources, and hence the profitability of the company (Harrigan et al., 2008). Thus, the following hypothesis is proposed: 
Hypothesis 1: The effort of electronic direct mailing (e-DM) positively influences perceived customer relationship quality.

\section{Interpersonal Communication}

Communication is one of the critical components of CRM. Interactivity is a crucial feature of the Internet, which allows people to participate actively in two-way online communications and electronic transactions. The Internet can help customers get product-related information and knowledge and allow them to have greater control in the information search process (Bezjian-Avery et al., 1998). Therefore, we propose the following hypothesis:

Hypothesis 2: Customers' perceived interpersonal communication positively influences perceived customer relationship quality.

\section{Preferential treatment}

Preferential treatment is the superior treatment an organization offers to regular customers that differentiates them from infrequent shoppers. Internet technologies facilitate the exploitation of customer data (Chaston and Mangles, 2003), which allows companies to implement fundamental CRM principles (e.g. calculate customer profitability and lifetime value and personalize product and service offerings), and helps create competitive advantage. Banks can provide customers with personalized products and services by investigating customer profiles and identifying those with high profit potential. For instance, preferential investment services or rates can be provided to those who might have a great interest in investment (e.g. customers with high net worth). The effects of customer retention can be improved for companies that apply greater effort in caring and providing preferential treatment to their customers (Hennig-Thurau and Klee, 1997). Thus, our following hypothesis is:

Hypothesis 3: Customers' perceived preferential treatment positively influences perceived customer relationship quality.

\section{Rewards}

Rewards are extra or special benefits, including discounts and coupons, an organization offers to customers. Rewards that directly relate to customers' loyal behaviours (e.g. repeated purchases) help to maintain customer loyalty (Berry, 1995). O'Brien and Jones (O'Brien and Jones, 1995) believed that rewards could create loyal relationships when they could align with company capabilities, and provide value to customers by having cash value, choice, aspirational value, relevance, and convenience. Therefore, the following hypothesis is proposed: 
Hypothesis 4: Customers' perceived reward from HSBC positively influences perceived customer relationship quality.

\section{Relationship Quality and Customer Loyalty}

Relationship quality is used to describe business relationships, which is typically conceptualized as a high-order construct comprising commitment, satisfaction, and trust (Crosby et al., 1990; Dorsch et al., 1998; Hewett et al., 2002). Customer loyalty is defined as customers' affection and commitment towards a product, service, brand, or organization (Oliver, 1999), which also means customers' intention to repurchase (Edwardsson et al., 2000). Loyalty is "the reflection of a customer's subconscious emotional and psychological need to find a constant source of value, satisfaction and identity” (Jenkinson, 1995). The most common behaviors of loyal customers include relationship continuance, increased scale or scope of relationship, and recommendations (Hallowell, 1996), dispersing favorable word of mouth and repurchasing the company's products (Dwyer et al., 1987; Fornell, 1992). Loyalty, therefore, is a crucial factor for a company to sustain and pursue success over time (Flavia'n et al., 2006; Keating et al., 2003). Hence, this behavior will be used as a key manifestation in this study on customer loyalty. The effect of e-CRM marketing effort on customer relationship quality between HSBC and customers, and the ultimate influences on loyalty will be examined. Based on the above studies, the relationship between customer relationship quality and customer loyalty is hypothesized as follows:

Hypothesis 5: Perceived customer relationship quality positively influences customer loyalty towards HSBC

\section{Research framework}

From the literature discussed above, a theoretical framework was developed. The framework identifies the relationship among the marketing effort of e-CRM, perceived customer relationship quality, and customer loyalty in Hong Kong's banking industry. Three research questions were developed: what is the influence of banks' e-CRM on customers' perception on relationship quality; what is the influence of perceived customer relationship quality on customer loyalty; and what does this model contribute to the retail banking industry? The five hypotheses derived from the research questions are then tested statistically. Figure 1 shows the framework suggesting the five links among the six constructs: electronic direct mail, interpersonal communication, preferential treatment, perceived reward, perceived customer relationship quality, and customer loyalty. 


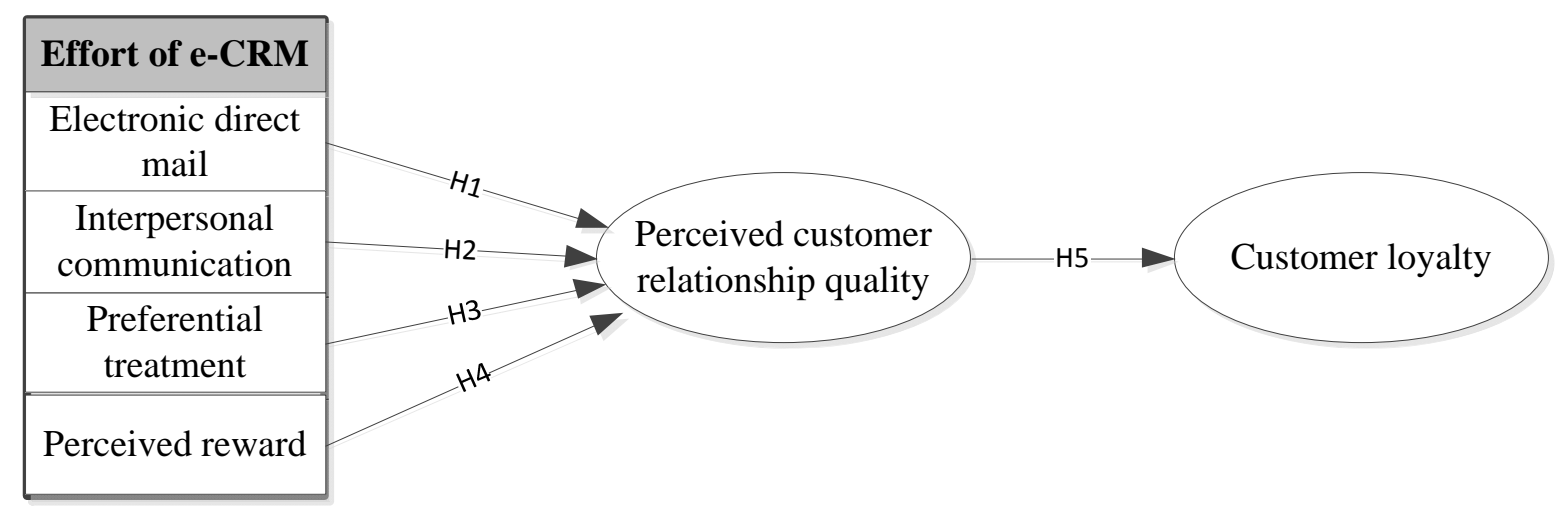

Figure 1 Theoretical framework

\section{SAMPLING AND DATA COLLECTION}

The target population for this study is HSBC customers in Hong Kong. We chose HSBC because it is world-renowned, it is the largest bank in Hong Kong, and its customers are perceived as reasonable representatives of the population. The sampling units consist of the heterogeneous population at a legal age to hold a savings and/or current account in HSBC. The respondents are customers using the retail banking services of HSBC, with different demographic profiles, residing in Hong Kong, who are representative of the adult population of Hong Kong.

First, a pilot study using in-depth interviews was conducted with 20 customers of HSBC, after the questionnaire had been discussed with two experts in the field of quantitative research. The purpose of this pilot study was to ensure the structure was well defined, and to minimize any possible errors. Two of the respondents commented that the questionnaire was too long, which led to an improved questionnaire as presented in this study. Finally, the questionnaire was condensed from 29 to 26 questions.

A self-administered questionnaire survey was then conducted to measure the marketing effort of e-CRM, relationship quality, and customer loyalty. The questionnaire is divided into three parts. The first part focused on the marketing effort of e-CRM, the second part on relationship quality, and the third part on customer loyalty. For every variable, respondents were asked to indicate agreement or disagreement with each statement using a seven-point Likert scale, ranging from "1 strongly disagree" to "7 - strongly agree." The last section contained multiple-choice questions related to the demographic profiles of the respondents. The respondents received a hyperlink that directed them to the Web site containing the questionnaire. They were allowed to respond to the questionnaire electronically and submit it online. 
Employing this approach provides a relatively easy means to study the opinions of a large group of customers in a limited time frame and at low cost. Also, the respondents could maintain their privacy when answering questions in relation to their financial service utilization and other demographic data.

Descriptive analysis was used to present a profile of the respondents and to identify the mean and standard deviation of each variable. Factor analysis was applied to determine whether the factor loadings were fragmented to another construct; an orthogonal factor analysis approach (Varimax) was used (Hair et al., 2010). The variables in this study are categorized into independent, dependent, and mediating variables. Four dimensions in the efforts of e-CRM are independent variables (electronic direct mail, interpersonal communication, preferential treatment, perceived reward), whereas perceived customer relationship quality is the mediating variable and customer loyalty is the dependent variable. All constructs are measured using a multi-item scale.

\section{Sample and Response Rate}

\section{RESULTS}

An email was sent to 150 customers of HSBC through a non-probability, convenience sampling method. 119 customers returned the questionnaires, with a 79\% response rate. The completed questionnaires were used for data analysis.

\section{Descriptive Statistics}

The percentages of female (52.1\%) and male (47.9\%) respondents are quite similar, indicating minimal sampling bias. The dominant age groups are 31-40 (42.9\%) and 21-30 (38.7\%), respectively. The majority of respondents are white-collar (28.6\%) workers, professional/managers (18.5\%) and salespersons (18.5\%). In addition, 24.4\% of respondents have an income level of HK\$15,001-20,000, and 20.2\% of them have an income level of HK\$20,001-25,000, which is higher than the average income $(H K \$ 11,000)$ of the population of Hong Kong (HKSAR Government Census and Statistics Department, 2011). Most of the respondents are either high school (33.6\%) or college $(27.7 \%)$ graduates, which is highly representative of the Hong Kong population, which comprises $32.1 \%$ secondary and $27.3 \%$ post-secondary school graduates. Overall, the sample includes a balanced number of the more educated subjects, with an above-average income level, which makes them ideal candidates for a study of banking services. 


\section{Factor Analysis and Reliability}

Regarding the pre-analysis testing for the suitability of the entire sample for factor analysis, the KMO measure of overall sampling adequacy was 0.938 . The high value of the KMO measure supports factor analysis. As shown in Table 1 , the appropriateness of factor analysis is also indicated by Bartlett's test of sphericity ( $\chi$ $2=1277.8, \mathrm{p}<0.001)$.

Table 1 KMO and Bartlett's test

\begin{tabular}{lll}
\hline Kaiser-Meyer-Olkin Measure of Sampling Adequacy & .938 \\
\hline Bartlett's Test of Sphericity & Approx. Chi-Square & 1277.845 \\
& df & 55 \\
& Sig. & .000 \\
\hline
\end{tabular}

Factor analysis was used to remove the redundant variables from the survey data and to reduce the number of variables into a definite number of dimensions. Factor analysis was performed using the principle component extraction method with varimax rotation (Hair et al., 2010). The sorted rotated values of factor loading with a minimum value of 0.5 are considered. One item from electronic direct mail was deleted from the analysis because the value for factor loading is below 0.5. Generally, factor loading represents how much a factor analysis explains a variable. High loading indicates that the factor strongly influences the variable. Table 2 shows that all factor loadings for the questionnaire items are above 0.5 .

Table 3 explains the results of factor analysis for perceived customer relationship quality. A cut-off value of 0.5 was used for the factor loadings. All items in the construct have a factor loading above 0.50 , which is regarded as high in the construct.

Table 4 explains the result of factor analysis for customer loyalty. A cut-off value of 0.5 was used for the factor loadings. All items in the construct have a factor loading above 0.50 , which is regarded as high in the construct.

Reliability of measures was assessed using the internal consistency measures of Cronbach's Alpha (Hair et al., 2010). From Tables 2 to 4, Cronbach's Alpha for all the variables ranged from 0.850 to 0.925 . All values exceed the minimum acceptable value of 0.7 for Cronbach's Alpha. 
Table 2 Four factors derived from rotated component matrix

\begin{tabular}{llllll}
\hline Variables and Questionnaire Items & \multicolumn{4}{c}{ Component } \\
& 1 & 2 & 3 & 4 \\
\hline
\end{tabular}

Perceived rewards (Cronbach's alpha $=.924$ )

HSBC often provides cash or bonus rewards through online $\quad .807$ channel.

I always receive cash or discounts rewards promotion provided $\quad .802$ by HBSC online channel.

I always receive the gift or lucky draw campaign promotions provided by HBSC online channel.

Preferential treatment (Cronbach's alpha $=.908$ )

I can enjoy exclusive benefits of being a HSBC membership.

I often receive HSBC online customers/ members exclusive

benefits and service (e.g. birthday discount, discounts for additional items, points for gifts, products offer the latest information, etc.).

I often receive personalized products or services promotion provided by HBSC online channel.

Interpersonal communication (Cronbach's alpha $=.925$ )

HSBC provides detailed online troubleshooting services (FAQ / FAQ).

HSBC provides a lot of online activities (online sweepstakes/ games, etc.).

HSBC provides a website opinions platform for customers' opinions expression.

Electronic Direct Mail (Cronbach's alpha $=.850$ )

I always receive HSBC's e-mail advertising or electronic newspapers.

HSBC's e-mail advertising or electronic newspapers can provide its latest products or services information.

Notes: Extraction Method: Principal Component Analysis.

Rotation Method: Varimax with Kaiser Normalization. 
Table 3 Rotated Component Matrix of Perceived Customer RElationship Quality

Variables and Questionnaire Items

Component

1

Perceived customer relationship quality (Cronbach's alpha $=.855$ )

0.888

I am willing to establish a long-term relationship with HSBC.

I trust the online information provided by HSBC.

0.886

Overall, I have a good and positive impression towards HSBC.

0.870

Notes: Extraction Method: Principal Component Analysis.

a. 1 component extracted.

Table 4 Rotated Component Matrix of Customer Loyalty

Variables and Questionnaire Items

Component

1

Customer loyalty (Cronbach's alpha $=.895)$

I will continue to choose / use HSBC’s products or services.

I will prioritize HSBC when selecting the same type of banking service 0.908 among banks.

I agree that I am a HSBC's loyal customer.

Notes: Extraction Method: Principal Component Analysis.

a. 1 component extracted.

\section{Multiple Regression}

Referring to Table 5, the Beta coefficients, which compared the relative strength of various predictors in the model, showed that perceived reward had the largest Beta coefficient, 0.460, while electronic direct mail had the smallest value, 0.336. The results also indicate that electronic direct mail, interpersonal communication, preferential treatment, and perceived reward have a significant influence on perceived relationship quality $(\mathrm{p}<0.001)$; therefore, hypotheses $\mathrm{H} 1, \mathrm{H} 2, \mathrm{H} 3$, and $\mathrm{H} 4$ are supported. In testing hypothesis H5, all the measurements on the customers' relationship quality were used. The unstandardized Beta coefficient is 0.647, which indicates a positive relationship between perceived customer relationship quality and customer loyalty, and the computed $\mathrm{p}$ value is smaller than 0.001. Therefore, 
hypothesis $\mathrm{H} 5$ is supported. The adjusted $\mathrm{R}$ Square was 0.414 , showing that the prediction power was moderate.

Table 5 Regression results (Unstandardized coefficient B)

\begin{tabular}{lcc}
\hline & \multicolumn{2}{c}{ Dependent Variables } \\
Independent Variables & $\begin{array}{c}\text { Perceived customer relationship } \\
\text { quality }\end{array}$ & Customer Loyalty \\
\hline Electronic direct mail & $.336^{* * *}$ & \\
Interpersonal & $.394^{* * *}$ & \\
communication & & \\
Preferential treatment & $.447^{* * *}$ & $.647 * * *$ \\
Perceived reward & $.460^{* * *}$ & \\
Perceived customer & & .419 \\
relationship quality & & .414 \\
& & 84.426 \\
R-Square & 0.680 & \\
Adjusted R-Square & 0.669 & \\
F Value & 60.538 & \\
\hline Notes: $n=119$ & & \\
$* * *$ Significant at $\mathrm{p}<0.001$ & &
\end{tabular}

\section{DISCUSSION}

This research was designed to investigate and explore the relations of the marketing efforts of e-CRM, relationship quality, and loyalty. According to the result, respondents generally had positive attitudes towards the e-CRM marketing tactics carried out by HSBC, including e-DM, interpersonal communication, preferential treatment, and rewards. The mean scores ranged from 5.39 to 5.66. Respondents preferred interpersonal communication and direct mail to preferential treatment and rewards. Amongst the four e-CRM marketing efforts, perceived reward was a relatively strong predictor and has a slightly higher impact on the model with the largest Beta coefficient (0.460). This implies that customers tend to have better relationship perception if the organization provides them with various types of rewards. Amongst the different types of rewards, customers preferred cash or near-cash rewards (e.g. cash, bonus, discounts) to non-cash rewards (e.g. gifts and lucky draws). The unstandardized Beta coefficient for customer relationship quality is 0.647, which indicates that customer relationship quality acts as a strong predictor for customer loyalty towards HSBC. This implies that HSBC should continuously promote its banking services to customers through various e-CRM efforts, and that the efforts are paying off. 
The findings supported the hypothesis that attitudes towards e-CRM marketing efforts and customer relationship quality towards HSBC are positively correlated. If the customers experience more e-CRM efforts, their perception of the quality of the relationship between the company and themselves will tend to be better. Moreover, according to the findings, $\mathrm{H} 5$ is supported. This implies that customers' relationship quality is positively related to customer loyalty. The study confirms the relationship between e-CRM efforts, customer relationship quality, and customer loyalty. In order for HSBC to increase customer loyalty and retain profitable customers, it should spend more time and resources developing effective e-CRM marketing strategies.

\section{Practical Implications}

In a fiercely competitive and mature marketplace, with over 150 competitors from around the world, HSBC is facing a serious challenge in maintaining its leadership position and market share, while seeking to sustain organic growth in its Hong Kong branches (HKSAR Government, 2011). Therefore, it is critical HSBC continues to invest in long-term relationship marketing efforts to boost its profitability. With one of the highest Internet usage rates in the world (87\%), which is still on the increase, active involvement in online activities has created tremendous opportunities for marketers to promote their products to Hong Kong consumers through different e-CRM endeavors (Nielsen, 2011). The inherent viral impact of Internet activities will create exponential growth in the positive impact of any successful marketing tactics, on the one hand, and on the other it will induce negative word of mouth concerning any unsuccessful tactics or poor service. The Internet is also bringing forth more severe competition as smaller players can now target customers at much lower cost. Therefore, while being the leader in Hong Kong's banking industry, HSBC should be aware of both the opportunities and threats brought about by the popularity of banking and customer services provided through the Internet.

To better utilize eCRM to maintain relationships with customers, we suggest HSBC improve its e-CRM as follows:

\section{e-DM}

HSBC should make its e-DM more attractive by incorporating more multimedia elements (e.g. video or video links of the latest promotions, flash banners or footers) to capture customers' attention so tailored messages can successfully reach customers instead of ending up in the junk mail box. 


\section{Interpersonal communication}

More resources should be invested to develop interpersonal communication on the Internet. This will help HSBC reduce operating costs, as the need to operate branches in prime and convenient locations would be minimized. This would have a significant impact on HSBC's profitability as land is limited in Hong Kong, and the rental cost of Class A office space in Hong Kong is the highest in the world, averaging US\$213.70 per square foot per year (HK Business, 2011).

Also, enabling customers to access information, ask questions, and receive answers through the Internet coincides with the Internet-savvy characteristics of people in Hong Kong (Synovate, 2010). Senior management support is required for HSBC to fully leverage the power of the Internet. On top of the official Web site, social media should also be used (e.g. Facebook, Weibo, etc). Resources should be allocated to exploit various e-CRM marketing tools, (e.g. search engine optimization, keyword advertising, external links, etc.).

Easy access, intuitive layout, user-friendliness, privacy and security should be some of the key considerations in developing e-CRM marketing tactics in order to serve customer needs and build long-term relationships.

\section{Preferential Treatment}

HSBC should offer different treatments to different customers after analyzing their lifetime value and profitability potential. Customers should be classified according to their past transaction records, demographic and psychographic profiles, and preferences. Unique and personalized services and promotional offerings should be developed to enable HSBC to personalize its relationships with customers. Exploiting this type of preferential treatment will enable HSBC to maximize profits and minimize the cost of maintaining customer relationships by improving relationship quality, which has a significant correlation with customer loyalty.

\section{Rewards}

Rewards are conducive to building customer loyalty. HSBC should invest more in tailoring rewards to their customers. To meet with the customers' preference for near-cash rewards, HSBC should incorporate more cash coupons, banking service discounts, merchant discounts, etc. A greater variety of rewards could be included to induce customer purchases. Electronic gadgets are attractive, as many Hong Kong people change their mobile phones at least once a year, and many have gadgets like tablet PCs, MP3s, etc. 
While a rewards scheme would help to develop loyalty, HSBC should also establish a greater exit barrier by increasing switching costs in order to combat growing competition in the banking industry. Also, the redemption process of the rewards program should be simplified to induce more customers' involvement and satisfaction. Instant rewards (e.g. online lucky draws) could induce more interaction between the company and its customers, and also fulfill the needs of many customers who are busy and impatient.

In sum, with the growing popularity of the Internet, HSBC and other service providers should make full use of the power and capability of e-CRM to help maximize returns on their business investments.

\section{Future Research}

Several issues were present due to the limited time and cost for the study. Future research should be developed with a larger sample size. A study of more than one bank could help researchers better understand the banking industry in Hong Kong. Differentiating the e-CRM effort in retail, commercial, and private banking could be conducive to the development of effective marketing strategies for bankers. To help marketers prioritize their efforts in e-CRM development, future research may also explore customers' frequency of usage and the habits of various Internet-related services, and a more elaborate list of e-CRM tools could be incorporated to seek customer opinions. The same research can also be applied to other industries or countries to examine the possible differences among diverse sectors and cultures.

\section{ACKNOWLEDGMENT}

The authors thank the Hong Kong Polytechnic University for supporting this research.

\section{REFERENCES}

Berry, L.L. (1995). Relationship marketing of services-growing interest, emerging perspectives. Journal of the Academy of Marketing Science, 23(4), 236-245. http://dx.doi.org/10.1177/009207039502300402

Bezjian-Avery, A., Calder, B. \& Iacobucci, D. (1998). New media interactive advertising vs. traditional advertising. Journal of Advertising Research, 38(4), 23-32.

Bolton, R.N., Lemon, K. \& Verhoef, P.C. (2004). The theoretical underpinnings of customer asset management: A framework and proposition for future research. Journal of the Academy of Marketing Science, 32(3), 271-292. http://dx.doi.org/10.1177/0092070304263341 
Bradshaw, D. \& Brash, C. (2001). Managing customer relatinships in the e-business world: How to peraonlise computer relationships for increased profitability. International Journal of Retail and Distribution Management, 29(12), 520-530.

Campbell, L. (1997). Orange sets up loyalty scheme. Marketing, 6.

Chaston, I. \& Mangles, T. (2003). Relationship marketing in online business-to-business markets: A pilot investigation of small UK manufacturing firms. European Journal of Marketing, 37(5/6), 753-773. http://dx.doi.org/10.1108/03090560310465134

Cho, Y., Im, Hiltz, R. \& Rjermestad, J. (2001). Causes and outcomes of online customer complaining behavior: implications for customer relationship management (CRM). Proceeding of the Seventh Americas Conference on Information System, 900-907.

Crosby, L.A., Evans, K.A. \& Cowles, D. (1990). Relationship quality in services selling: An interpersonal influence perspective. Journal of Marketing, 54(3), 68-81. http://dx.doi.org/10.2307/1251817

Day, S.G. \& Hubbard, J.K. (2003). Customer relationships go digital. Business Strategy Review, 14(1), 17-26. http://dx.doi.org/10.1111/1467-8616.00240

Dorsch, M.J., Swanson, S.R. \& Kelley, S.W. (1998). The role of relationship quality in the stratification of vendors as perceived by customers. Journal of Academy of $\begin{array}{lll}\text { Marketing } \quad \text { Science, 26(2), } & \text { 128-142. }\end{array}$ http://dx.doi.org/10.1177/0092070398262004

Duncan, T. \& Moriaty, S.E. (1998). A communication-based marketing model for managing relationship. Journal of Marketing, 62(2), 1-13. http://dx.doi.org/10.2307/1252157

Dwyer, F.R., Schurr, P.H. \& Oh, S. (1987). Developing buyer-seller relationships. Journal of Marketing, 51(2), 11-27. http://dx.doi.org/10.2307/1251126

Edwardsson, B., Johnson, M.D., Gustafsson, A. \& Strandvik, T. (2000). The effects of satisfaction and loyalty on profits and growth: Products versus services. Total Quality Management, 11(7), 917-927.

Flavia'n, C., Guinah'u, M. \& Gurrea, R. (2006). The role played by perceived usability, satisfaction and consumer trust on website loyalty. The International Journal of Information Systems Applications, 43(1), 1-14.

Forbes, (2011). Global 2000 leading companies. Retrieved from http://www.forbes.com/companies/hsbc-holdings.

Forchit, K.A. \& Cochran, K. (1999). Using data mining and data warehousing techniques. Industrial Management and Data Systems, 99(5), 189-196. 
Fornell, C. (1992). A national customer satisfaction barometer: The Swedish experience. Journal of Marketing, 56(1), 6-21. http://dx.doi.org/10.2307/1252129

Gronroos, C. (1994). From marketing mix to relationship marketing: Towards a paradign shift in marketing. Asia-Australia Marketing Journal 2(1), 9-29. http://dx.doi.org/10.1108/00251749410054774

Hair, J.F., Jr., Black, W.C., Babin, B.J. \& Anderson, R.E. (2010). Multivariate Data Analysis. 7th ed., Prentice Hall, Upper Saddle River, N.J.

Hallowell, R. (1996). The relationship of customer satisfaction, customer loyalty and profitability: An empirical study. International Journal of Service Industries Management, 7(4), 27-42. http://dx.doi.org/10.1108/09564239610129931

Hamid, A. \& Kassim, N.R. (2004). Internet technology as a tool in customer relationship management. Journal of American Academy of Business, 4(1/2), 103-108.

Hanson, W. (2000). Principles of internet marketing. South-Western College Publishing, Cincinnati, $\mathrm{OH}$.

Harrigan, P., Ramsey, E. \& Ibbotson, P. (2008). e-CRM in SMEs: An exploratory study in Northern Ireland. Marketing Intelligence and Planning, 26(4), 385-404. http://dx.doi.org/10.1108/02634500810879296

Hennig-Thurau, T. \& Klee, A. (1997). The impact of customer satisfaction and relationship quality and customer retention: a critical reassessment and model development. Psychology and Marketing, 14(8), 737-764. http://dx.doi.org/10.1002/(SICI)1520-6793(199712)14:8<737::AID-MAR2>3.3. $\mathrm{CO} ; 2-\mathrm{Z}$

Hewett, K., Money, R.B. \& Sharma, S. (2002). An exploration of the moderating role of buyer corporate culture in industrial buyer-seller relationships. Journal of Academy of Marketing Science, 30(3), 229-239. http://dx.doi.org/10.1177/00970302030003004

HK Business, (2011). Hong Kong Class A office rent most expensive worldwide. Retrieved March 11, 2011, from http://hongkongbusiness.hk/commercial-property/news/hong-kong\%E2\%80\%99s -class-office-rent-most-expensive-worldwide

HKSAR Government, (2011). Financial Services. Retrieved from http://www.gov.hk/en/about/abouthk/factsheets/docs/financial_services.pdf.

HKSAR Government, (2012). Hong Kong as a Service Economy. Retrieved from http://www.gov.hk/en/about/abouthk/factsheets/docs/service_economy.pdf. 
HKSAR Government Census and Statistics Department, (2011). Summary results of 2011 population census. Retrieved April 12, 2011, from http://www.census2011.gov.hk/pdf/summary-results.pdf.

HSBC, (2011). HSBC's history. Retrieved from http://www.hsbc.com/1/2/about/history/history\#change.

Iyer, G.R., Miyazaki, A.D., Grewal, D. \& Giordano, M. (2002). Linking web-based segmentation to pricing tactics. Journal of Product and Brand Management, 11(4), 288-300. http://dx.doi.org/10.1108/10610420210442175

Jackson, R. \& Wang, P. (1994). Strategic database marketing. NTC Business Books, Lincolnwood, IL.

Jenkinson, A. (1995). Retailing and shopping on the internet. International Journal of Retail and Distribution Management, 24(3), 26-37.

Keating, B., Rugimbana, R. \& Quazi, A. (2003). Differentiating between service quality and relationship quality in cyberspace. Managing Service Quality, 13(3), 217-232. http://dx.doi.org/10.1108/09604520310476481

Krishnan, M.S. \& Ramaswamy, V. (1999). Customer satisfaction for financial services: The role of products, services and information technology. Management Science, 45(9), 1194-1290. http://dx.doi.org/10.1287/mnsc.45.9.1194

Lee-Kelley, L., Gilbert, D. \& Mannicom, R. (2003). How e-CRM can enhance customer loyalty. Marketing Intelligence and Planning, 21(4), 239-248. http://dx.doi.org/10.1108/02634500310480121

Mojtaba, P.S. (2009). Impact of customer relationship management (CRM) in the Iran banking sector. International Journal of Organizational Innovation, 2(1), 225-251.

Morgan, R.M. \& Hunt, S.D. (1994). The commitment-trust theory of relationship marketing. Journal of $\quad$ Marketing, 58(3), http://dx.doi.org/10.2307/1252308

Morris, D.S., Barnes, B.R. and Lynch, J.E. (1999). Relationship marketing needs total quality management. Total Quality Management, 659. http://dx.doi.org/10.1080/0954412997659

Nielsen, (2011). Hong Kong's Digital Landscape is Dynamic and Evolving. Retrieved March, 2012, from http://blog.nielsen.com/nielsenwire/online_mobile/ hong-kong\%E2\%80\%99s-digital-landscape-is-dynamic-and-evolving/

O'Brien, L. \& Jones, C. (1995). Do rewards create loyalty. Harvard Business Review, 73(3), 75-83.

Oliver, R.L. (1999). Whence consumer loyalty. Journal of Marketing, 63(4), 33-44. http://dx.doi.org/10.2307/1252099 
Palmatier, R.W., Dant, R.P., Grewal, D. \& Evans, K.R. (2006). Factors influencing the effectiveness of relationship marketing: a meta-analysis. Journal of Marketing, 70(4), 136-153. http://dx.doi.org/10.1509/jmkg.70.4.136

Porter, M.E. (2001). Strategy and the Internet. Harvard Business Review, 79(3), 62-78.

Rahman, Z. (2005). Customer experience management: A case study of an Indian bank. Database Marketing and Customer Strategy Management, 13(3), 203-221. http://dx.doi.org/10.1057/palgrave.dbm.3240298

Reichheld, F. (1996). The loyalty effect: The hidden force behind growth, profits, and lasting value. Harvard Business School Press, Boston.

Reichheld, F. \& Sasser, E., Jr (1990). Zero defection: Quality comes to services. Harvard Business Review, 68(5), 105-111.

Reichheld, F.F. \& Schefter, P. (2000). E-loyalty: Your secret weapon on the Web. Harvard Business Review, 78(4), 105-113.

Romano, N., Jr (2001). An agenda for electronic commerce customer relationship management research. Proceeding of the Seventh Americas Conference on Information System, 831-833.

Sheth, J.N., Rajenda, S.S. \& S., A. (2000). Antecedents and consequences of the growth of customer-centric marketing. Journmal of the Academy of Marketing Science, 28(Winter), 55-66.

Synovate, (2010). Lifestyles and consumption habits of four generations of Hong Kong consumers. Retrieved from http://www.synovate.com/ news/article/2010/03/lifestyles-and-consumption-habits-of-four-generations-of-h ong-kong-consumers-revealed-by-synovate.html

The Standard, The Standard, (2011, 10 September 2011). HK in top five of world bank rankings. Retrieved 30 October 2011, from http://www.thestandard.com.hk/breaking_news_detail.asp?id=5708\&.

Thorbjornsen, H., Supphellen, M., Nysveen, H. \& Pedersen, P.E. (2002). Building brand relationships online: A comparison of two interactive applications. Journal of Interactive Marketing, 16(3), 17-34. http://dx.doi.org/10.1002/dir.10034

Winer, R.S. (2001). A framework for customer relationship management. California Management Review, 43(4), 89-105. http://dx.doi.org/10.2307/41166102

Yin, C.K. (1999). Customer behaviour loyalty: A segmentation model and analysis. Journal of Business Research, 44(2), 75-92.

Yoon, D., Choi, S.M. \& Sohn, D. (2008). Building customer relationships in an electronic age: The role of interactivity of e-commerce web sites. Psychology and Marketing, 25(7), 602-618. http://dx.doi.org/10.1002/mar.20227 
Zineldin, M. (2000). Beyond relationship marketing: Technologicalship marketing. Marketing Intelligence and Planning, 18(1), 9-23. http://dx.doi.org/10.1108/02634500010308549 
